\title{
Mafic dykes at the southwestern margin of Eastern Ghats belt: Evidence of rifting and collision
}

\author{
S Bhattacharya ${ }^{1, *}$, A K Chaudhar ${ }^{2}$ and W Teixeira ${ }^{3}$ \\ ${ }^{1}$ Indian Statistical Institute, Kolkata 700 108, India. \\ ${ }^{2}$ Indian Institute of Technology Roorkee, Roorkee 247 667, India. \\ ${ }^{3}$ Geoscience Institute, Rua do Lago 562, CEP 05508-080, Sao Paulo University, Brasil. \\ *e-mail: samar.bhattacharya@gmail.com
}

The southwestern margin of the Eastern Ghats Belt characteristically exposes mafic dykes intruding massif-type charnockites. Dykes of olivine basalt of alkaline composition have characteristic trace element signatures comparable with Ocean Island Basalt (OIB). Most importantly strong positive $\mathrm{Nb}$ anomaly and low values of $\mathrm{Zr} / \mathrm{Nb}$ ratio are consistent with OIB source of the mafic dykes. $\mathrm{K}-\mathrm{Ar}$ isotopic data indicate two cooling ages at 740 and $530 \mathrm{Ma}$. The Pan-African thermal event could be related to reactivation of major shear zones and represented by leuco-granite vein along minor shear bands. And $740 \mathrm{Ma}$ cooling age may indicate the low grade metamorphic imprints, noted in some of the dykes. Although no intrusion age could be determined from the present dataset, it could be constrained by some age data of the host charnockite gneiss and Alkaline rocks of the adjacent Prakasam Province. Assuming an intrusion age of $\sim 1.3 \mathrm{Ga}, \mathrm{Sr}-\mathrm{Nd}$ isotopic composition of the dykes indicate that they preserved time-integrated LREE enrichment. In view of the chemical signatures of OIB source, the mafic dykes could as well be related to continental rifting, around $1.3 \mathrm{Ga}$, which may have been initiated by intra-plate volcanism.

\section{Introduction}

Mafic dyke swarms are common in most Archaean cratons, including those of the Indian Shield (Ernst et al 1995; Murthy 1987). Srivastava and co-workers have studied mafic dyke swarms of the Bastar craton, adjoining the high-grade belt of the Eastern Ghats, and suggested a continental rift environment for the emplacement of these dykes (Srivastava et al 1996, 2000; Srivastava and Singh 2003). Srivastava and Singh (2003) also described two sets of different ages, namely middle Archaean and Palaeoproterozoic, respectively, based on field relations and available age data. Mafic dykes are also commonly observed at the south-western margin of the Eastern Ghats belt, adjoining the Bastar and east Dharwar cratons. The geochemistry of these dykes, along with some isotopic data from the dykes, may provide insights to the tectonic setting of emplacement as well as mantle source characteristics (Sheraton and Black 1981; Neogi et al 1996). In the present paper we report, geochemistry, including trace and rare earth element geochemistry of some mafic dykes, along with some age data on the dykes of the Naraseraopet, adjoining the Prakasam alkaline province. This may provide some insights to the tectonic setting of the dykes in relation to the rift-valley magmatism of the Prakasam alkaline province.

\section{Geological setting}

The high-grade Eastern Ghats belt along the east coast of India, and bounded by Singhbhum and Bastar cratons to the north and west respectively, is described as a compressional orogen

Keywords. Mafic dykes; OIB source; rift-volcanism; Pan-African reactivation. 


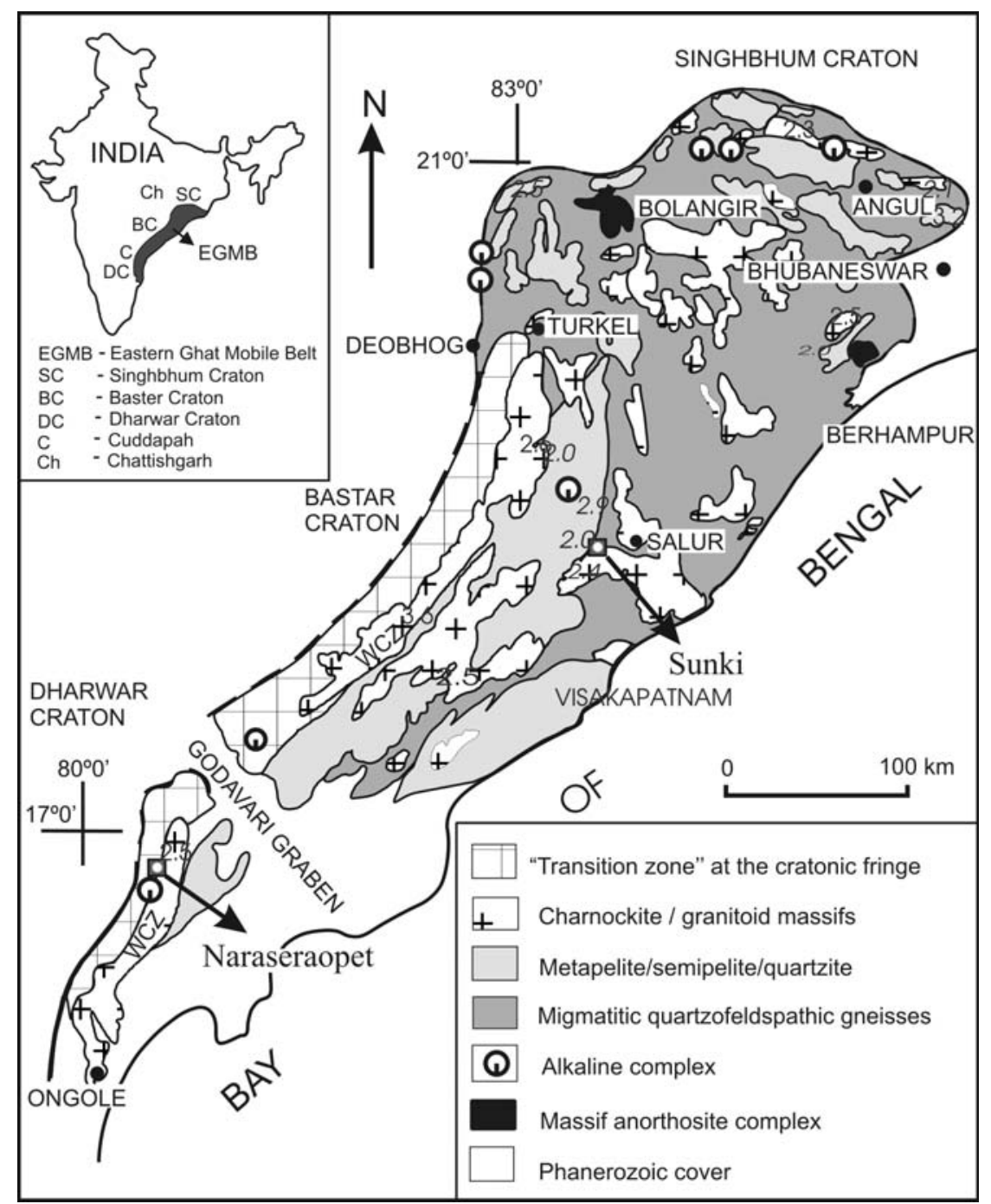

Figure 1. Generalized geological map of the Eastern Ghats belt, with important locations, including dyke locations.

(Bhattacharya 1997; Bhattacharya and Sen 2003). The lithological make-up of this belt could be described in terms of three broad groups, namely, metapelitic granulites, charnockite-enderbite gneisses and associated mafic granulites and migmatitic gneisses. Additionally, a transition zone along significant length of the western margin was also described (Ramakrishnan et al 1998).

The Eastern Ghats granulite terrain is characterized by polyphase deformation and polycyclic metamorphism and partial melting in different crustal precursors (Halden et al 1982; Dasgupta et al 1992, 1994; Bhattacharya et al 1994; Sen et al 1995; Sen and Bhattacharya 1997; Dasgupta and Sengupta 1998; Bhattacharya and Kar 2002).

The south-western margin of the high-grade Eastern Ghats belt, India, is characterized by the presence of mafic dykes, the granulite country rocks, both around Jeypore, to the north of the Godabari graben, and around Naraseraopet, to the south, are massif-type charnockites (Bhattacharya 2004; Bhattacharya et al 2010). The present study is focused on the mafic dykes of the Naraseraopet area (figure 1). The charnockite-enderbite gneisses of Jeypore are of Archaean age, $2.5 \mathrm{Ga}$ reported from complexly zoned zircon (Simmat and Raith 2008). But south of Godavari graben, charnockiteenderbite gneisses record a much younger age, namely $\sim 1.6 \mathrm{Ga}$ (Kovach et al 2001; Simmat and Raith 2008; Bhattacharya et al 2010). It is important to note that the Prakasam alkaline complex, representing rift-valley magmatism, occurs to the west of the Ongole domain of the Eastern Ghats granulite belt. Vijay Kumar and Leelanandam (2008) considered this rifting between 1.3 and $1.5 \mathrm{Ga}$, based on $\mathrm{U}-\mathrm{Pb}$ zircon ages reported from the alkaline rocks of the Prakasam province. Around Naraseraopet in this domain, some leucogranite veins along small scale shear bands are also observed, which even truncates the dyke 


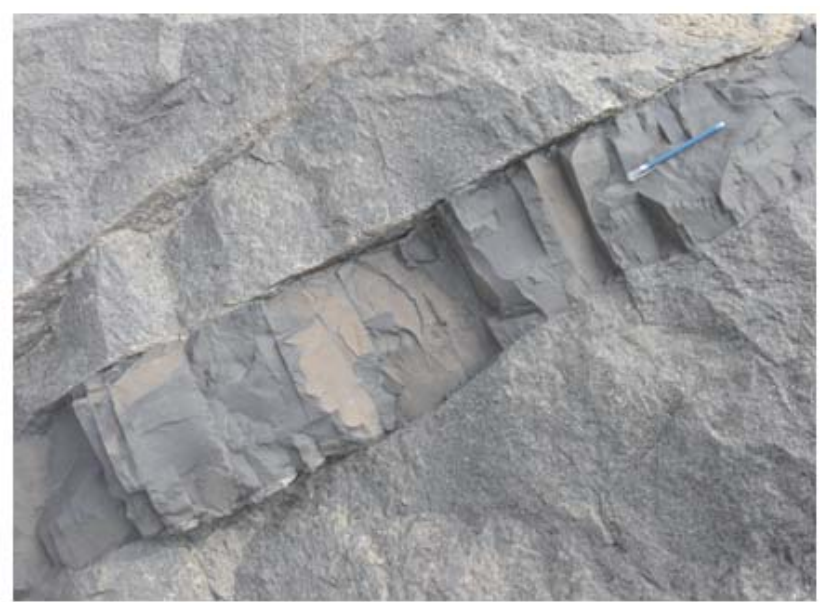

(a)

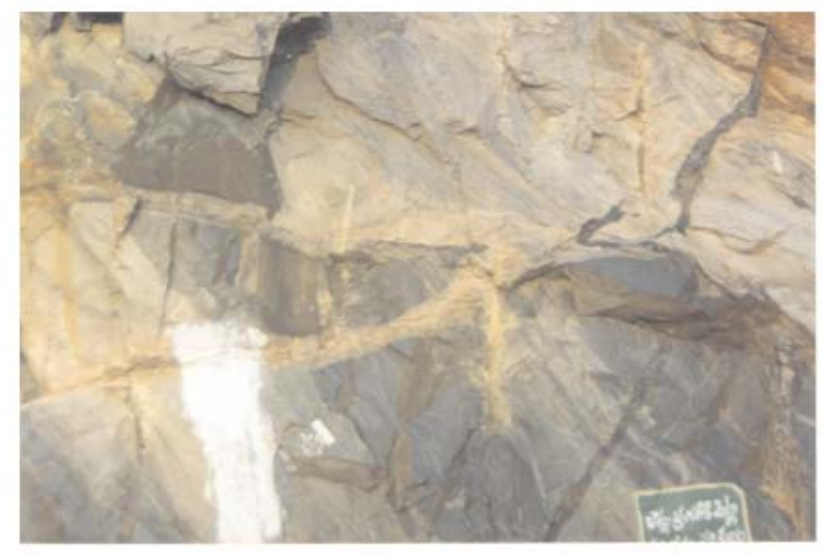

(b)

Figure 2. Field photographs. (a) Mafic dyke intruding charnockite gneiss, around Naraseraopet, AP (b) Thin mafic dyke, truncated and displaced along leuco-granite vein.

(figure 2a, 2b). Apparently, there are two sets of dykes; the relatively larger ones (up to $1 \mathrm{~m}$ wide and up to $100 \mathrm{~m}$ in length) have nearly east-west strike $\left(75^{\circ}-92^{\circ} \mathrm{E}\right)$. The smaller dykes $(<10 \mathrm{~cm}$ wide and $<1 \mathrm{~m}$ in length) are somewhat variable in orientation $\left(126^{\circ}-168^{\circ} \mathrm{E}\right)$.

\section{Petrography}

The mafic dykes are commonly characterized by ophitic texture, defined by clinopyroxene and plagioclase (figure 3a). The following mineralogical assemblages were recorded: Orthopyroxeneclinopyroxene-plagioclase-Fe- $\mathrm{Ti} \quad$ oxides \pm olivine; plagioclase-amphibole-biotite-orthopyroxene-Fe-Ti oxides \pm garnet; and orthopyroxene-plagioclaseclinopyroxene-epidote-muscovite. Accessory phases include calcite and zeolite (as cavity fillings). Sometimes orthopyroxene also occurs at margin of olivine phenocryst (figure 3b). Zoning in Olivine phenocrysts is also a noticeable feature (figure $3 \mathrm{~b}$ ).

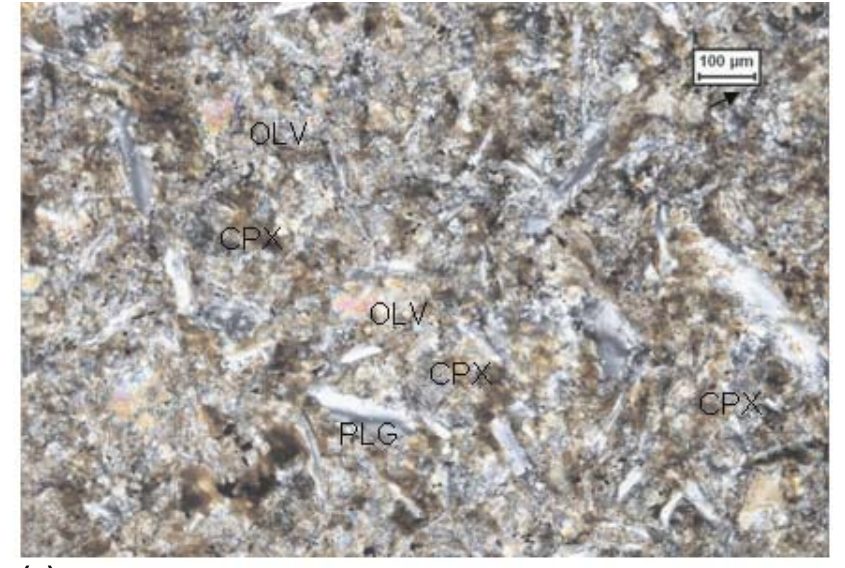

(a)

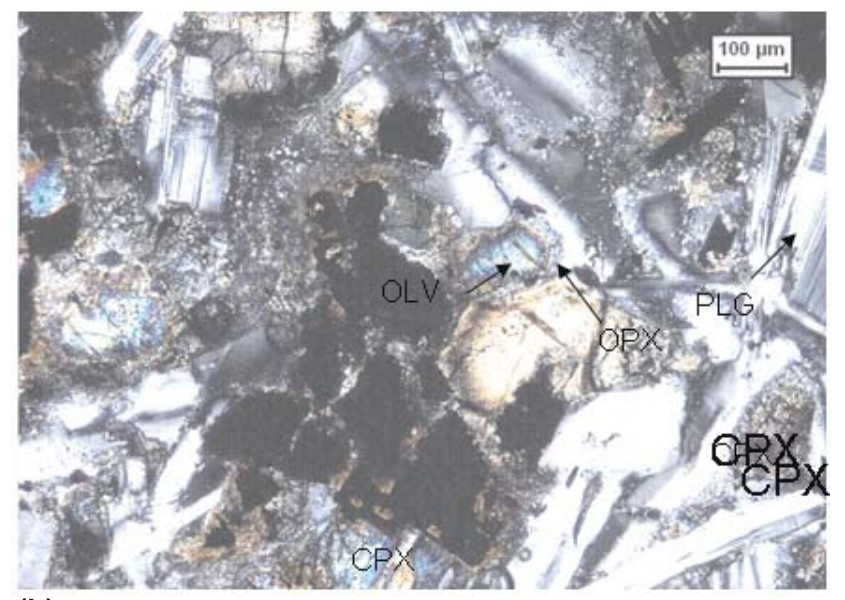

(b)

Figure 3. Photomicrographs. (a) Medium grained pyroxene-plagioclase defines an ophitic texture. (b) Fine grained clinopyroxene-plagioclase define ophitic texture; Olivine phenocryst with orthopyroxene rim at the right.

Secondary amphibole and biotite are also common in many of the samples.

Thus petrographically these dykes could be described as olivine-dolerite, meta-dolerite and hornblende-dolerite and deformation-induced recrystallization are also occasionally observed.

\section{Geochemistry}

\subsection{Analytical procedure}

Major and minor element oxides were analyzed by XRF (X-ray Fluorescence) at NGRI, Hyderabad and trace elements were analyzed by ICP-MS (Inductively Coupled Plasma-Mass Spectrometry), at IIC, IIT, Roorkee. Operating condition for XRF machine was $20 / 40 \mathrm{KV}$ and nominal analysis time was 300 seconds for all major oxides. For the XRF analysis the overall accuracy (\% relative standard deviation) for major and minor oxides are given as less than $5 \%$ and for trace elements is less 
Table 1. Composition of the mafic dykes, around Naraseraopet, AP.

\begin{tabular}{|c|c|c|c|c|c|c|c|c|c|}
\hline Sample no. & $\mathrm{F} 5 / 1 / 04$ & $\mathrm{~A} 4 / 1$ & $\mathrm{G} 1 / 4 \mathrm{~A}$ & G5/1 & $\mathrm{J} 1 / 2 / 04$ & $\mathrm{~F} 6 / 3$ & $\mathrm{~J} 3 / 2 / 04$ & I3/2/04 & $\mathrm{I} 3 / 2$ \\
\hline $\mathrm{SiO}_{2}$ & 47.74 & 46.96 & 49.84 & 48.16 & 47.13 & 49.95 & 48.8 & 52.51 & 46.08 \\
\hline $\mathrm{Al}_{2} \mathrm{O}_{3}$ & 17.34 & 16.03 & 15.96 & 17.27 & 15.87 & 15.96 & 16.89 & 17.74 & 14.66 \\
\hline $\mathrm{Fe}_{2} \mathrm{O}_{3}(\mathrm{~T})$ & 12.83 & 11.43 & 13.1 & 12.78 & 9.99 & 11.69 & 10.32 & 12.91 & 10.43 \\
\hline $\mathrm{MnO}$ & 0.15 & 0.14 & 0.16 & 0.15 & 0.14 & 0.13 & 0.12 & 0.15 & 0.14 \\
\hline $\mathrm{MgO}$ & 6.06 & 9.54 & 5.03 & 5.42 & 10.01 & 7.79 & 7.94 & 3.44 & 13.13 \\
\hline $\mathrm{CaO}$ & 7.66 & 8.19 & 5.66 & 6.3 & 8.88 & 7.97 & 4.6 & 6.59 & 7.77 \\
\hline $\mathrm{Na}_{2} \mathrm{O}$ & 3.01 & 2.81 & 3.12 & 3.27 & 2.22 & 3.69 & 3.21 & 2 & 2.29 \\
\hline $\mathrm{K}_{2} \mathrm{O}$ & 1.49 & 1.81 & 2.92 & 2.52 & 2.04 & 0.54 & 4.01 & 0.93 & 2.54 \\
\hline $\mathrm{TiO}_{2}$ & 1.83 & 1.65 & 1.93 & 1.86 & 1.33 & 0.84 & 1.6 & 1.69 & 1.42 \\
\hline $\mathrm{P}_{2} \mathrm{O}_{5}$ & 0.36 & 0.21 & 0.79 & 0.58 & 0.28 & 0.14 & 0.77 & 0.84 & 0.32 \\
\hline LOI & 0.8 & 1.5 & 1.8 & 1.4 & 0.7 & 1.3 & 2.1 & 1.5 & 1.7 \\
\hline Sum & 99.27 & 100.27 & 100.3 & 99.71 & 98.59 & 100 & 100.36 & 100.3 & 100.48 \\
\hline \multicolumn{10}{|c|}{ Trace elements in ppm } \\
\hline $\mathrm{Cu}$ & 62 & 66 & 35 & 28 & 60 & 38 & 33 & 85 & 37 \\
\hline $\mathrm{Cr}$ & 85 & 500 & 8 & 6 & 411 & 359 & 263 & 36 & 667 \\
\hline Co & 83 & 63 & 57 & 89 & 55 & 59 & 33 & 99 & 59 \\
\hline $\mathrm{Ni}$ & 58 & 102 & 11 & 17 & 94 & 110 & 65 & 24 & 140 \\
\hline $\mathrm{Zn}$ & 106 & 74 & 113 & 102 & 58 & 64 & 57 & 99 & 62 \\
\hline V & 229 & 222 & 177 & 216 & 210 & 162 & 88 & 246 & 195 \\
\hline $\mathrm{Sc}$ & 25 & 27 & 17 & 20 & 26 & 19 & 13 & 26 & 22 \\
\hline $\mathrm{Zr}$ & 71 & 47 & 30 & 36 & 23 & 14 & 126 & 10 & 33 \\
\hline $\mathrm{Sr}$ & 483 & 327 & 770 & 621 & 394 & 359 & 932 & 310 & 332 \\
\hline $\mathrm{Nb}$ & 25 & 21 & 73 & 49 & 28 & 19 & 92 & 16 & 35 \\
\hline $\mathrm{Ta}$ & 4 & 3 & 10 & 8 & 4 & 3 & 11 & 4 & 5 \\
\hline $\mathrm{Li}$ & 1 & 1 & 3 & 2 & 2 & 2 & 3 & 2 & 1 \\
\hline $\mathrm{Rb}$ & 30 & 46 & 66 & 47 & 27 & 10 & 110 & 12 & 32 \\
\hline $\mathrm{Ba}$ & 872 & 998 & 3758 & 1959 & 1090 & 313 & 2485 & 2328 & 1087 \\
\hline $\mathrm{Y}$ & 23 & 21 & 31 & 30 & 17 & 13 & 22 & 48 & 17 \\
\hline $\mathrm{Th}$ & 3 & 1 & 5 & 5 & 2 & 1 & 9 & 3 & 3 \\
\hline $\mathrm{U}$ & 1 & 1 & 1 & 1 & 1 & 1 & 2 & 1 & 1 \\
\hline $\mathrm{La}$ & 26.16 & 15.25 & 76.01 & 62.00 & 26.62 & 14.04 & 83.36 & 66.44 & 26.41 \\
\hline $\mathrm{Ce}$ & 51.68 & 32.17 & 146.8 & 122.85 & 52.03 & 26.79 & 150.40 & 132.71 & 51.53 \\
\hline $\operatorname{Pr}$ & 6.45 & 4.32 & 17.94 & 15.10 & 6.31 & 3.24 & 16.40 & 16.76 & 6.21 \\
\hline $\mathrm{Nd}$ & 24.76 & 17.73 & 64.43 & 55.18 & 22.93 & 12.22 & 53.70 & 63.64 & 22.08 \\
\hline $\mathrm{Sm}$ & 5.28 & 4.37 & 11.15 & 10.07 & 4.33 & 2.84 & 8.12 & 12.26 & 4.09 \\
\hline $\mathrm{Eu}$ & 2.00 & 1.69 & 3.48 & 3.00 & 1.76 & 1.09 & 2.58 & 3.22 & 1.62 \\
\hline $\mathrm{Gd}$ & 5.70 & 4.64 & 11.97 & 10.84 & 4.98 & 3.05 & 9.64 & 12.84 & 4.74 \\
\hline $\mathrm{Tb}$ & 0.77 & 0.68 & 1.32 & 1.26 & 0.61 & 0.44 & 0.95 & 1.62 & 0.57 \\
\hline Dy & 4.13 & 3.79 & 5.83 & 5.77 & 3.18 & 2.44 & 3.97 & 8.16 & 3.03 \\
\hline Ho & 0.83 & 0.80 & 1.14 & 1.15 & 0.67 & 0.51 & 0.78 & 1.71 & 0.62 \\
\hline Er & 1.67 & 1.57 & 2.38 & 2.37 & 1.40 & 1.00 & 1.75 & 3.52 & 1.31 \\
\hline $\operatorname{Tm}$ & 0.31 & 0.30 & 0.40 & 0.40 & 0.26 & 0.19 & 0.30 & 0.65 & 0.24 \\
\hline $\mathrm{Yb}$ & 1.90 & 1.90 & 2.55 & 2.50 & 1.65 & 1.23 & 1.93 & 4.02 & 1.58 \\
\hline $\mathrm{Lu}$ & 0.27 & 0.27 & 0.35 & 0.35 & 0.23 & 0.18 & 0.28 & 0.56 & 0.23 \\
\hline $\mathrm{Ba} / \mathrm{Nb}$ & 34.36 & 46.51 & 51.55 & 40.00 & 39.23 & 16.58 & 27.05 & 144.28 & 30.84 \\
\hline $\mathrm{Nb} / \mathrm{Y}$ & 1.13 & 1.03 & 2.36 & 1.63 & 1.64 & 1.42 & 4.11 & 0.34 & 2.14 \\
\hline $\mathrm{Rb} / \mathrm{Y}$ & 1.35 & 2.22 & 2.14 & 1.56 & 1.59 & 0.74 & 4.93 & 0.24 & 1.91 \\
\hline $\mathrm{Rb} / \mathrm{Sr}$ & 0.06 & 0.14 & 0.09 & 0.08 & 0.07 & 0.03 & 0.12 & 0.04 & 0.10 \\
\hline $\mathrm{La} / \mathrm{Nb}$ & 1.03 & 0.71 & 1.04 & 1.27 & 0.96 & 0.74 & 0.91 & 4.12 & 0.75 \\
\hline $\mathrm{La} / \mathrm{Ta}$ & 5.96 & 4.59 & 7.90 & 7.73 & 6.17 & 4.21 & 7.51 & 17.66 & 4.93 \\
\hline$(\mathrm{La} / \mathrm{Sm})_{\mathrm{N}}$ & 3.12 & 2.19 & 4.29 & 3.88 & 3.87 & 3.11 & 6.46 & 3.41 & 4.06 \\
\hline$(\mathrm{Gd} / \mathrm{Lu})_{\mathrm{N}}$ & 2.65 & 2.11 & 4.26 & 3.88 & 2.67 & 2.16 & 4.35 & 2.86 & 2.57 \\
\hline $\mathrm{Eu} / \mathrm{Eu}^{*}$ & 1.11 & 1.14 & 0.92 & 0.87 & 1.15 & 1.13 & 0.89 & 0.78 & 1.12 \\
\hline $\mathrm{Nb} / \mathrm{La}$ & 0.97 & 1.41 & 0.96 & 0.79 & 1.04 & 1.34 & 1.10 & 0.24 & 1.33 \\
\hline $\mathrm{Nb} / \mathrm{Ce}$ & 0.49 & 0.67 & 0.50 & 0.40 & 0.53 & 0.70 & 0.61 & 0.12 & 0.68 \\
\hline$(\mathrm{La} / \mathrm{Sm})_{\mathrm{N}}$ & 3.12 & 2.20 & 4.30 & 3.88 & 3.87 & 3.11 & 6.46 & 3.41 & 4.06 \\
\hline $\mathrm{La} / \mathrm{Yb}$ & 14 & 8 & 30 & 25 & 16 & 11 & 43 & 17 & 17 \\
\hline $\mathrm{Th} / \mathrm{Ta}$ & 0.65 & 0.31 & 0.5 & 0.57 & 0.52 & 0.41 & 0.84 & 0.8 & 0.54 \\
\hline $\mathrm{Nb} / \mathrm{U}$ & 29 & 21 & 73 & 49 & 28 & 19 & 46 & 16 & 35 \\
\hline \multirow[t]{2}{*}{$\mathrm{Zr} / \mathrm{Nb}$} & 2.8 & 2.2 & 0.4 & 0.7 & 0.8 & 0.7 & 1.4 & 0.6 & 0.9 \\
\hline & Olv-dol & Meta-dol & Hbl-dol & Hbl-dol & Olv-dol & Meta-dol & Meta-dol & Banded & Meta-dol \\
\hline
\end{tabular}




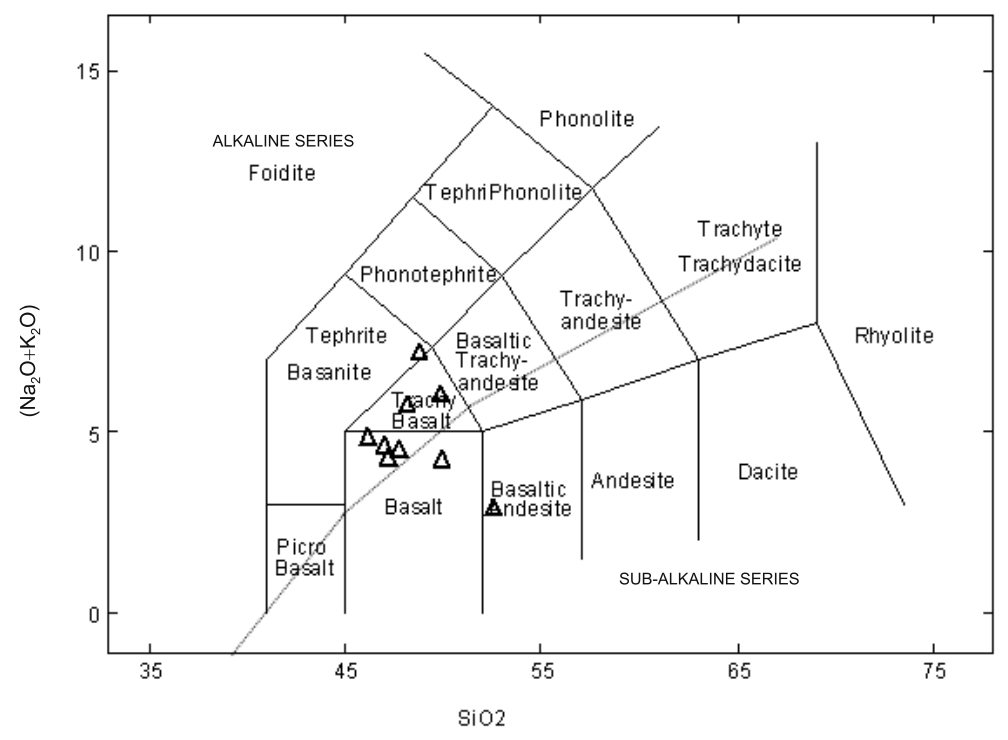

Figure 4. Total alkalis versus silica diagram after Le Maitre (1989).

than $12 \%$. The average precision is reported as better than $1.5 \%$. For ICP-MS analysis at Institute Instrumentation Centre, Indian Institute of Technology, Roorkee, the average precision was $4.1 \%$ RSD.

\subsection{Results}

In table 1, we present bulk analytical data for nine dyke samples. Except the sample with recrystallized and banded structure $(\mathrm{I} / 3 / 2)$, all the dykes are olivine normative, and two samples even contain olivine $(\mathrm{F} / 5 / 1$ and $\mathrm{J} / 1 / 2)$. Two samples are also nepheline normative (I3/2 and A4/1) in addition to normative olivine. The mafic dykes show alkaline geochemical characteristics (figure 4). Representative variation diagrams show the characteristic fractionation trends (figure 5). A positive correlation between $\mathrm{MgO}$ and $\mathrm{CaO}$ can be seen, while $\mathrm{P}_{2} \mathrm{O}_{5}$ and $\mathrm{TiO}_{2}$ increase with decreasing $\mathrm{MgO}$. Increasing $\mathrm{CaO}$ and decreasing $\mathrm{P}_{2} \mathrm{O}_{5}$ with increasing $\mathrm{MgO}$, could relate to fractionation of phases like plagioclase and clinopyroxene and suppression of apatite crystallization. Also increasing $\mathrm{Ni}$ with increasing $\mathrm{MgO}$ suggests olivine and plagioclase fractionation (figure 5). High-field strength elements and rare-earth elements are thought to be immobile during lowto-medium grade metamorphism or alteration. Selected HFSE, Y, Zr, and Nd variation in relation to $\mathrm{MgO}$ are shown in figure 6. Here $\mathrm{Y}$ and $\mathrm{Nd}$ show distinct negative correlation with $\mathrm{MgO}$; and $\mathrm{Zr}$ does not show any relation with $\mathrm{MgO}$. Particularly, negative correlation of $\mathrm{Y}$ and $\mathrm{Nd}$ with $\mathrm{MgO}$ is consistent with the incompatible element enrichment in more evolved compositions.
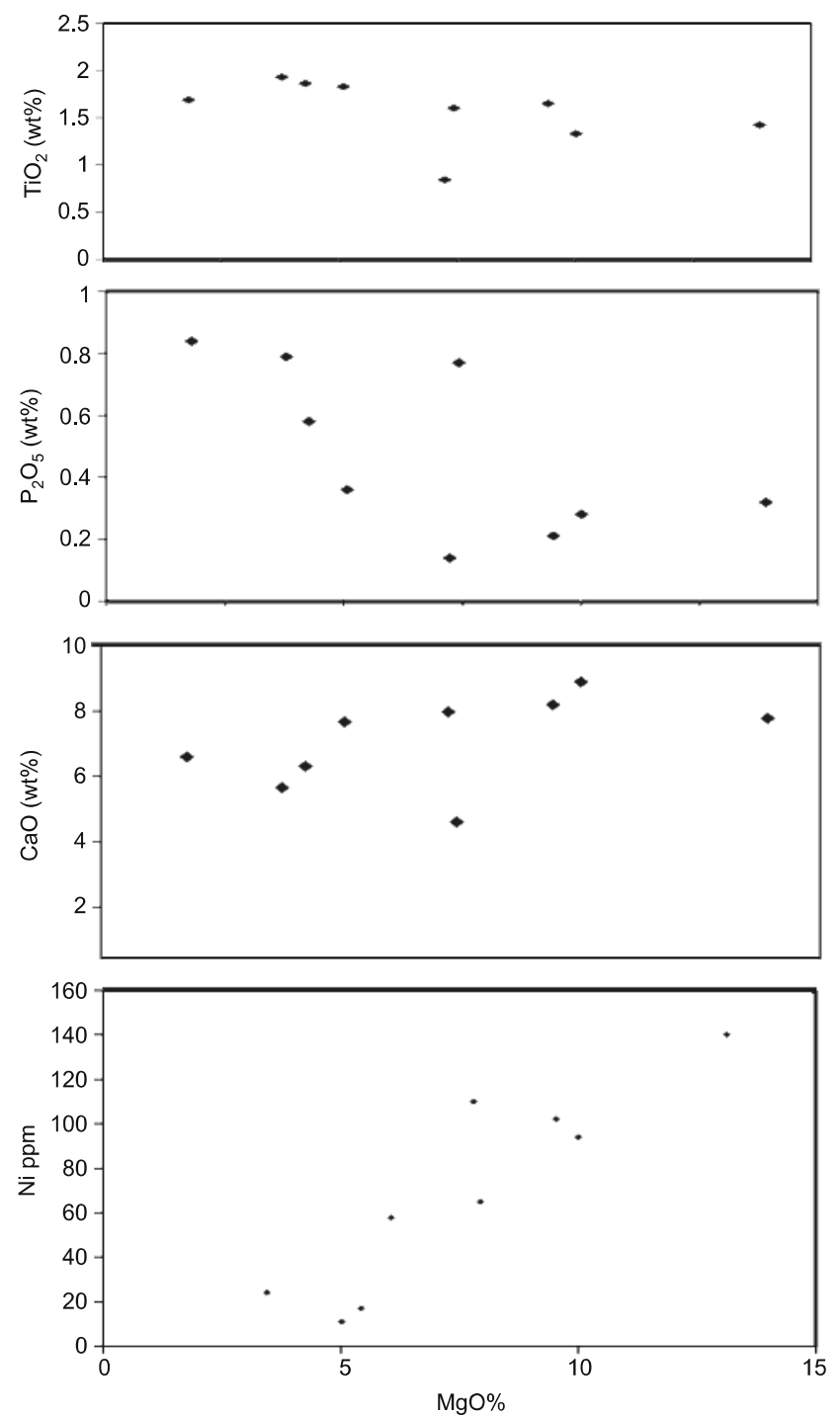

Figure 5. Variation diagrams for $\mathrm{CaO}, \mathrm{P}_{2} \mathrm{O}_{5}$ and $\mathrm{TiO}_{2}$ and $\mathrm{Ni}$ against $\mathrm{MgO}$. 

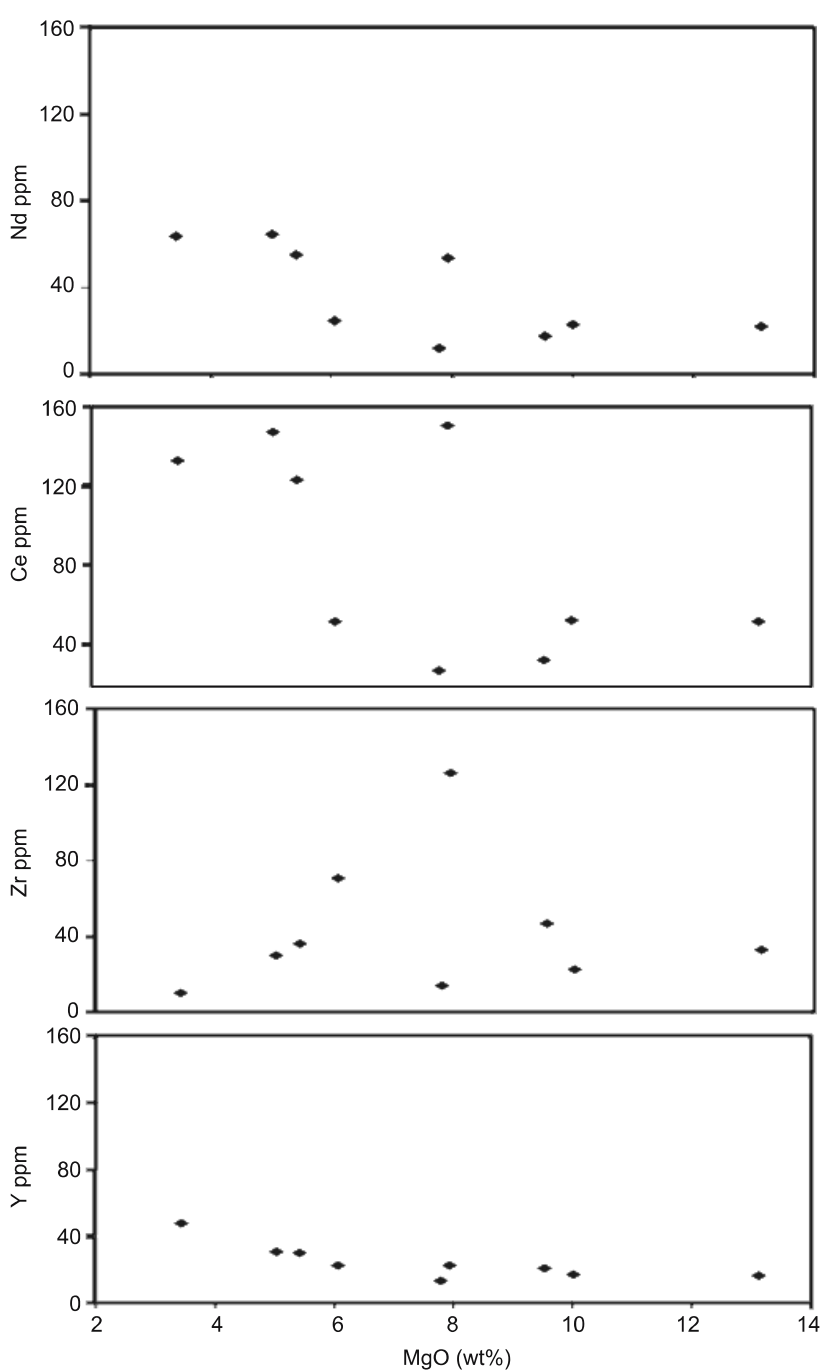

Figure 6. Variation diagrams for HFSE Y, Zr, Ce and Nd against $\mathrm{MgO}$.

Primitive mantle normalized multi-element spider plot (figure 7) shows Ba spike, large negative $\mathrm{K}$ and $\mathrm{Ti}$ anomalies, and small positive $\mathrm{Sr}$ anomaly, while positive $\mathrm{Nb}$ anomaly is significant. This pattern is similar to that of average OIB, particularly $\mathrm{Nb}$ spike is characteristic of OIB source, although incompatible element concentrations are higher.

Certain trace element ratios, namely, Th/Ta, $\mathrm{La} / \mathrm{Yb}$ may characterize tectonic setting of the basaltic dykes (Condie 1994). In particular, high values of $\mathrm{La} / \mathrm{Yb}$ between 8 and 43 imply either crustal contamination during emplacement or a previous event of crustal recycling in the mantle source region. However, $\mathrm{Nb} / \mathrm{U}$ ratios vary between 16 and 73 , with an average of 36 . This is somewhat lower than the average of 52 in OIB (Hofmann 2004); but such high values can not be accounted for by crustal contamination. Importantly, low values of $\mathrm{Zr} / \mathrm{Nb}$, between 0.4 and 2.2 are similar to those observed in OIB source.

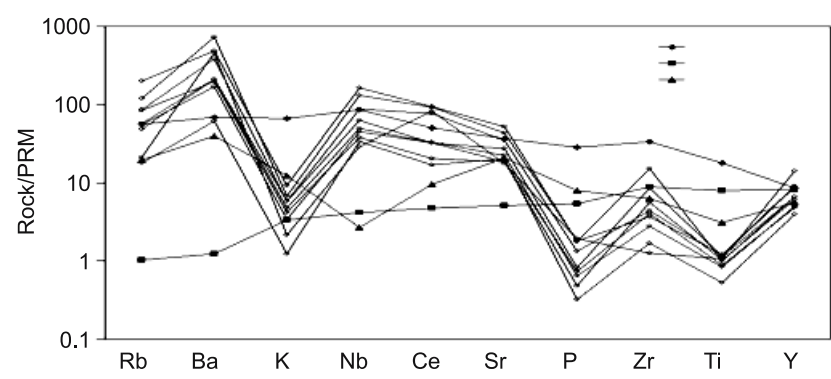

Figure 7. Multi-element spider plot for the mafic dykes, compared with basalts of different tectonic setting. Normalization after McDonough and Sun (1995).

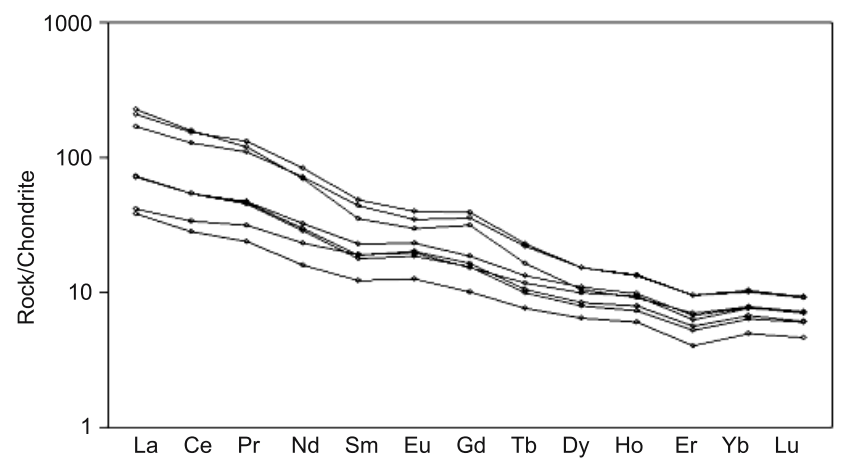

Figure 8. REE plot of the mafic dykes. Normalization after McDonough and Sun (1995).

LREE fractionation is more $(2.2$ to 6.5$)$ than HREE fractionation (2.1 to 4.4). Chondrite normalized REE plot (figure 8) shows small LREE enrichment, while HREE pattern is relatively flat. Small positive gadolinium anomaly is observed in some samples, similar to that of BD1 dykes of Bastar craton (Srivastava and Singh 2004) and the quartz-dolerite dykes of Scourie (Tarney 1992). These samples also have small negative $\mathrm{Eu}$ anomaly, which may indicate plagioclase fractionation or may have been in equilibrium with a plagioclase-bearing mantle source.

\section{Isotopic signatures}

The dykes commonly cut across the charnockitic gneiss, which records a granulite facies event dated $1.6 \mathrm{Ga}$ by $\mathrm{U}-\mathrm{Pb}$ isotopic data of zircons (Bhattacharya et al 2010). The whole rock $\mathrm{Rb}-\mathrm{Sr}$ and $\mathrm{Sm}-\mathrm{Nd}$ systems have failed to define any meaningful age. However, these whole rock systems could provide some information on the mantle source characteristics.

\subsection{Analytical procedure}

$\mathrm{Rb}-\mathrm{Sr}$ and $\mathrm{Sm}-\mathrm{Nd}$ isotopic analyses were undertaken at Indian Institute of Technology, Roorkee, 
Table 2. Sr-Nd isotopic composition of the mafic dykes, around Naraseraopet, AP.

\begin{tabular}{lccccccccc}
\hline Sample & Rock type & ${ }^{87} \mathrm{Rb} /{ }^{86} \mathrm{Sr}$ & ${ }^{87} \mathrm{Sr} /{ }^{86} \mathrm{Sr}$ & ${ }^{147} \mathrm{Sm} /{ }^{144} \mathrm{Nd}$ & ${ }^{143} \mathrm{Nd} /{ }^{144} \mathrm{Nd}$ & $\begin{array}{c}\varepsilon_{\mathrm{Sr}} \\
1.3 \mathrm{Ga}\end{array}$ & $\begin{array}{c}\varepsilon_{\mathrm{Sr}} \\
1.5 \mathrm{Ga}\end{array}$ & $\begin{array}{c}\varepsilon_{\mathrm{Nd}} \\
1.3 \mathrm{Ga}\end{array}$ & $\begin{array}{c}\varepsilon_{\mathrm{Nd}} \\
1.5 \mathrm{Ga}\end{array}$ \\
\hline J-6 & Basalt & 0.3287 & 0.714605 & 0.21247 & 0.511316 & 78 & 74 & -28 & -28 \\
$\mathrm{I}-3 / 2$ & Basalt & 0.22 & 0.711643 & 0.17969 & 0.511137 & 65 & 59 & -26 & -26 \\
$\mathrm{G}-5 / 1$ & Basalt & 0.1261 & 0.707942 & 0.16913 & 0.511415 & 37 & 35 & -19 & -19 \\
$\mathrm{G}-1 / 4$ & Basalt & 0.1839 & 0.710084 & 0.15537 & 0.511432 & 52 & 48 & -16 & -16 \\
\hline
\end{tabular}

Table 3. K-Ar isotopic data for mafic dykes, Naraseraopet, AP.

\begin{tabular}{lccccc}
\hline Sample & Rock type & $\% \mathrm{~K}$ & $\begin{array}{c}\operatorname{Ar}^{40} \text { radiogenic } \\
\left(10^{-6} \mathrm{~cm}^{3} \mathrm{STP} / \mathrm{g}\right)\end{array}$ & $\begin{array}{c}\mathrm{Ar}^{40} \text { Atm } \\
(\%)\end{array}$ & $\begin{array}{c}\mathrm{K}-\mathrm{Ar} \text { age } \\
(\mathrm{Ma})\end{array}$ \\
\hline SB01 & Basalt & $1.2856 \pm 90$ & 45.92 & 1.64 & $743.2 \pm 14.1$ \\
SB02 & Basalt & $3.4174 \pm 171$ & 82.05 & 1.28 & $531.5 \pm 9.5$ \\
SB03 & Basalt & $0.9868 \pm 138$ & 25.47 & 3.44 & $565.8 \pm 14.7$ \\
\hline
\end{tabular}

using Thermal Ionisation Mass Spectrometer (TIMS). Rb, Sr and REE fractions are separated using Bio-Rad AG50 X8 ion exchange resin in silica glass columns. Sm and Nd are separated from REE fractions using LN Spec Resin. The total procedure blank in the laboratory is less than $8 \mathrm{ng}$ of $\mathrm{Sr}$ and $\sim 1 \mathrm{ng}$ of $\mathrm{Nd}$ during the period of analysis. Rb, $\mathrm{Sr}, \mathrm{Sm}$ and $\mathrm{Nd}$ abundances were determined by isotope dilution method. The isotope ratios were measured on a Thermo Electron TRITON T1 fully automatic variable multi-collector mass spectrometer at the Institute Instrumentation Centre of the Indian Institute of Technology, Roorkee, based on $2 \sigma$ error statistics. Measured ratios for isotopic composition are normalized to ${ }^{86} \mathrm{Sr} /{ }^{88} \mathrm{Sr}=0.1194$ for $\mathrm{Sr}$ and ${ }^{146} \mathrm{Nd} /{ }^{144} \mathrm{Nd}=0.7219$ for $\mathrm{Nd}$. The measured ratio of ${ }^{87} \mathrm{Sr} /{ }^{86} \mathrm{Sr}$ for SRM-987 Sr standard was $0.710248 \pm 10$ (quoted value 0.710245 ) and ${ }^{143} \mathrm{Nd} /{ }^{144} \mathrm{Nd}$ for Ames $\mathrm{Nd}$ standard was $0.512138 \pm 4$ (quoted value 0.512138). For age determination we also undertook $\mathrm{K}$-Ar isotopic analysis at the Geochronological Center, Sao Paulo University, Brazil. Crushed and sized samples of whole rock separates weighing $0.2 \mathrm{gm}$ were fused by induction heating in ultra-high vacuum systems employing $\mathrm{Cu}-\mathrm{CuO}$ and titanium for gas purification. The gas released was 'spiked' for isotope dilution analysis using individual aliquots of pure $\mathrm{Ar}^{38}$. Mass spectrometry was carried out by the static method on a Reynolds-type mass spectrometer. Potassium determinations on $0.2 \mathrm{gm}$ split samples were made by flame photometry using a Baird-Atomic research flame photometer with a lithium internal standard. The chemical procedure was essentially that described by Brannock and Berthold (1949). The $\mathrm{K}^{40}$ constants employed in calculation in this paper are $\lambda_{\text {tot }}=0.530 \times 10^{-9} \mathrm{y}^{-1}, \quad \lambda_{K}=0.585 \times 10^{-10} \mathrm{y}^{-1}$ and atom $\% \mathrm{~K}^{40}$ in $\mathrm{K}=0.0119$. Precision of potassium analysis of $1.2 \%$ on average and that for Ar within about $2 \%$.

\subsection{Results}

Analytical data for $\mathrm{Rb}-\mathrm{Sr}$ and $\mathrm{Sm}-\mathrm{Nd}$ isotopes are presented in table 2. From these data age of intrusion of the dykes could not be determined. However, we have calculated epsilon values of $\mathrm{Sr}$ and $\mathrm{Nd}$ at $1.3 \mathrm{Ga}$ and presented in figure 8 . The results of $\mathrm{K}-\mathrm{Ar}$ isotopic analysis for three dyke samples is given in table 3 . It is interesting to note that two distinct cooling ages, namely 550 and $740 \mathrm{Ma}$ recorded in the dykes.

Presence of dykes of different ages in the same locality and field setting, namely intrusive into massif-type charnockite, around Naraseraopet, the southwest margin of the Ongole domain of the Eastern Ghats belt have important implications on the nature of this plate margin. Further, the sample SB03 includes biotite of hydrothermal origin, and hence the age $\sim 530$ Ma may be interpreted as emplacement in submerged conditions. In the $\mathrm{Sr}-\mathrm{Nd}$ correlation diagram (figure 9 ) the samples plot in quadrant IV, indicating sources that were enriched in $\mathrm{Rb}$ and depleted in Sm. The high ${ }^{87} \mathrm{Sr} /{ }^{86} \mathrm{Sr}$ values and negative $\varepsilon$ values indicate that they preserved time-integrated LREE enrichment.

\section{Discussion}

Unlike the two sets of dykes (BD1 and BD2) described from the Bastar craton by Srivastava and Singh 2003, 2004) there are no chemical distinction between the two sets of dykes in the present study; both having distinctly high $\mathrm{La} / \mathrm{Yb}$ ratios, indicating possible crustal contamination or crustal recycling in the mantle source. A high value of $\mathrm{Nb} / \mathrm{U}$ 


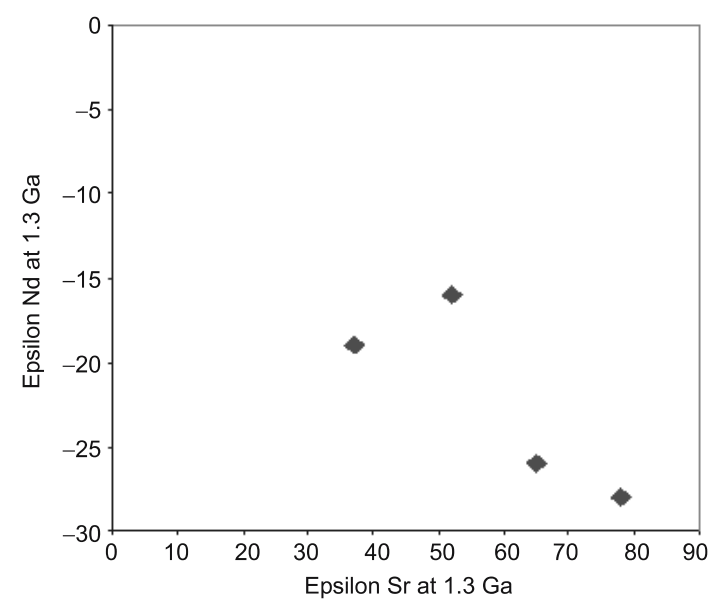

Figure 9. Sr-Nd correlation diagram for the mafic dykes, calculated at $1.3 \mathrm{Ga}$.

ratios, on the other hand, argues against crustal contamination. Most importantly strong positive $\mathrm{Nb}$ anomaly and low values of $\mathrm{Zr} / \mathrm{Nb}$ ratio are consistent with OIB source of the mafic dykes.

For such mafic dykes isotopic age data are so far lacking and their distinct ages are only interpreted from field evidence (Srivastava and Singh 2004). Age data is presented in this study for the first time.

Two distinct cooling ages are recorded in the dykes. It is important to note that some thin mafic dykes were observed to have been dismembered along small scale shear zones, which is also marked by leuco-granite emplacement. The ca. $550 \mathrm{Ma}$ is here interpreted as locally intense thermal event associated with reactivation of major shear zones. It is important that a crustal scale shear zone occurs along a significant length of the western margin of the Eastern Ghats belt (Bhattacharya 2004). Also this later resetting event may be represented by significant recrystallization noted in one sample. Further, both the group of ages has been reported from the northern margin of the Eastern Ghats belt (Crowe et al 2001). Most importantly, Pan-African reactivation of major shear zones was also documented from the northern margin by these authors.

Although, the intrusion age of the dykes could not be determined, it must post date $1.6 \mathrm{Ga}$ charnockite-enderbite gneisses (Simmat and Raith 2008; Bhattacharya et al 2010), to which the dykes have an intrusive relation. On the other hand, rift-valley magmatism of the adjoining Prakasam alkaline province, are constrained by $\mathrm{U}-\mathrm{Pb}$ zircon data, between 1.3 and 1.5 Ga (Vijay Kumar and Leelanandam 2008 and references therein). In view of the chemical signatures of OIB source, the mafic dykes could as well be related to continental rifting, around $1.3 \mathrm{Ga}$, which may have been initiated by intra-plate volcanism. Enriched isotopic composition of $\mathrm{Sr}$ calculated at $1.3 \mathrm{Ga}$, is also consistent with an OIB source.

The nature of this cratonic margin is complex, and based on U-Pb age dating of the alkaline complexes of the Prakasam province, it has been suggested that multiple episodes of alkaline magmatism occurred in the same zone (Vijay Kumar and Leelanandam 2008). According to Burke et al (2003), ARCs are expected to be erupted in rifts that overlie sutures in which older $(\sim 1.5 \mathrm{Ga})$ and deformed ARCs are burrried to mantle lithosphere depths. In that context, the younger and undeformed alkaline complexes $\sim 520$ Ma may signify the rifting phase and the Pan-African reactivation. The younger cooling age $\sim 530 \mathrm{Ma}$, as represented by the small and sheared mafic dykes could be another manifestation of the complex evolutionary history of this cratonic margin.

\section{Acknowledgement}

Indian Statistical Institute provided the infrastructural facilities.

\section{References}

Bhattacharya S 1997 Evolution of Eastern Ghats granulite belt of India in a compressional tectonic regime and juxtaposition against iron ore craton of Singhbhum by oblique collision-transpression; Proc. Indian Acad. Sci. 106 65-75.

Bhattacharya S, Sen S K and Acharyya A 1994 Structural setting of the Chilka Lake granulite-migmatiteanorthosite suite with emphasis on the time relation of charnockites; Precamb. Res. 66 393-409.

Bhattacharya S and Sen S K 2003 Thermotectonic modelling of convergent orogens: Mantle involvement and implications for P-T-t paths; GEOS 14 7-12.

Bhattacharya S and Kar Rajib 2002 High-temperature dehydration melting and decompressive $\mathrm{P}-\mathrm{T}$ path in a granulite complex from the Eastern Ghats, India; Contrib. Mineral. Petrol. 143 175-191.

Bhattacharya S 2004 High-temperature crustal scale shear zone at the western margin of the Eastern Ghats granulite belt, India: Implications for rapid exhumation; J. Asian Earth Sci. 24 281-290.

Bhattacharya S, Das P, Chaudhary A K and Saw A K 2010 Mafic granulite xenoliths in the Eastern Ghats granulite belt: Implications for lower crustal processes in the southeastern Indian Peninsula; Indian J. Geol. 80 53-67.

Bhattacharya S 2009 Mafic crustal xenoliths from the east Indian shield: Evidence for recycled continental crust in the Palaeoproterozoic and Archaean mantle; Abstract, Goldsmidt Conference, Davos.

Brannock W and Berthold S 1949 The determinations of sodium and potassium in silicate rocks by flame photometer; U.S. Geol. Surv. Bull. 992 1-14.

Burke K, Ashwal L D and Webb S J 2003 New way to map old sutures using deformed alkaline rocks and carbonatites; Geology 31 391-394. 
Condie K C 1994 Plate Tectonics and Crustal Evolution; Butterworth-Heinemann Lincare House Publisher, pp. 282.

Crowe W A, Cosca M A and Harris L B $2001{ }^{40} \mathrm{Ar} /{ }^{39} \mathrm{Ar}$ geochronology and Neoproterozoic tectonics along the northern margin of the Eastern Ghats belt in north Orissa, India; Precamb. Res. 108 237-266.

Dasgupta S, Sengupta P, Fukuoka M and Chakrabarti S 1992 Dehydration melting, fluid buffering and decompressional $\mathrm{P}-\mathrm{T}$ path in a granulite complex from the Eastern Ghats, India; J. Metamor. Geol. 10 777-788.

Dasgupta S, Sanyal S, Sengupta P and Fukuoka M 1994 Petrology of granulites from Anakapalle-evidence for Proterozoic decompression in the Eastern Ghats, India; J. Petrol. 35 433-459.

Dasgupta S and Sengupta P 1998 Re-working of an isobarically cooled deep continental crust: Evidence of decompressive $\mathrm{P}-\mathrm{T}$ trajectory from the Eastern Ghats belt, India; Indian J. Geol. 70 133-144.

Ernst R E, Buchan K L and Palmer H C 1995 Giant dyke swarms: Characteristics, distribution and geotectonic applications; In: Physics and chemistry of dykes (eds) Baer G and Heinmann, A.A. Balkema Rotterdam, $3-21$.

Halden N M, Bowes D R and Dash B 1982 Structural evolution of migmatites in a granulite facies terrane: Precambrian crystalline complex of Angul, Orissa, India; $R$. Soc. Edinburgh 73 109-118.

Hofmann A W 2004 Sampling mantle heterogeneity through Oceanic basalts: Isotopes and trace elements; In: The Mantle and Core (ed.) Carlson R W, Treatise on Geochemistry 2 61-101.

Kovach V P, Simmat R, Rickers K, Berezhnaya N G, Salnikova E B, Dobmeier C, Raith M M, Yakovleva S Z and Kotov A B 2001 The western charnockite zone of the Eastern Ghats Belt, India: An independent crustal province of late Archaean $(2.8 \mathrm{Ga})$ and Paleoproterozoic (1.7-1.6 Ga) terrains; Gondwana Res. 4 666-667.

Le Maitre R W 1989 A classification of igneous rocks and glossary of terms; Blackwell, Oxford.

McDonough W F and Sun S S 1995 The composition of the Earth; Chem. Geol. 120 223-253.

Murthy N G K 1987 Mafic dyke swarms of the Indian Shield; In: Mafic dyke swarms (eds) Halls H C and Fahrig W F, Geol. Assoc. Canada Spec. Paper 34 393-400.
Neogi S, Miura H and Hariya Y 1996 Geochemistry of the Dongargarh volcanic rocks, Central India: Implications for the Precambrian mantle; Precamb. Res. 76 77-91.

Ramakrishnan M, Nanda J K and Augustine P F 1998 Geological evolution of the Proterozoic Eastern Ghats Mobile Belt; Geol. Surv. India Spec. Publ. 44 1-21.

Sen S K, Bhattacharya S and Acharyya A 1995 A multistage pressure-temperature record in the Chilka Lake granulites: The epitome of metamorphic evolution of Eastern Ghats, India? J. Meteor. Geol. 13 287-298.

Sen S K and Bhattacharya S 1997 Dehydration melting of micas in the Chilka Lake khondalites: The link between the metapelites and granitoids; Proc. Indian Acad. Sci. (Earth Planet. Sci.) 106 277-297.

Sheraton J W and Black L P 1981 Geochemistry and geochronology of Proterozooic tholeiite dykes of East Antarctica: Evidence for mantle metasomatism; Contrib. Mineral. Petrol. 78 305-317.

Simmat R and Raith M M 2008 U-Th-Pb monazite geochronometry of the Eastern Ghats Belt, India: Timing and spatial disposition of poly-metamorphism; Precamb. Res. 162 16-39.

Srivastava R K, Hall R P, Verma R and Singh R K 1996 Contrasting Precambrian mafic dykes of the Bastar craton, Central India: Petrological and geochemical characteristics; J. Geol. Soc. India 48 537-546.

Srivastava R K, Singh R K and Verma R 2000 Juxtaposition of India and Antarctica during the Precambrian: Inferences from geochemistry of mafic dykes; Gondwana Res. 3 227-234.

Srivastava R K and Singh R K 2003 The Paleoproterozoic dolerite dyke swarm of the southern Bastar craton, Central-East India: A supporting evidence for the Columbia Supercontinent; In: Milestones in Petrology (ed.) Mohan A, Geol. Soc. India Memoir 52 163-177.

Srivastava R K and Singh R K 2004 Trace element geochemistry and genesis of Precambrian sub-alkaline mafic dykes from the central Indian craton: Evidence for mantle metasomatism; J. Asian Earth Sci. 23 373-389.

Tarney J 1992 Geochemistry and significance of mafic dykes swarms in the Proterozoic; Dev. Precamb. Geol. 10 151-179.

Vijaya Kumar K and Leelanandam C 2008 Evolution of the Eastern Ghats belt, India: A plate tectonic perspective; J. Geol. Soc. India 72 720-749. 